\title{
Why are anopheline mosquitoes not present in the Seychelles?
}

Vincent Robert ${ }^{1 *}$, Gérard Rocamora ${ }^{2}$, Simon Julienne ${ }^{3}$, Steven M Goodman ${ }^{4}$

\begin{abstract}
Background: Species of anopheline mosquitoes are largely distributed over emerged lands around the world and, within the tropics, few areas are without these insects, which are vectors of malaria parasites. Among the exceptions is the Seychelles archipelago in the western Indian Ocean. However, in the Aldabra island group, located in the extreme western portion of the archipelago, Anopheles gambiae s.l. was introduced, leading to massive proliferation and then elimination, with the most recent autochthonous malaria cases recorded in 1931.
\end{abstract}

Methods: In order to re-examine the absence of anopheline mosquitoes in the Seychelles, an entomological field survey was conducted in December 2008 at 17 sites on four granitic islands, including Mahé and Praslin, and ten sites on coralline atolls in the extreme west, including Aldabra.

Results: No evidence of larval or adult anophelines was found at the surveyed sites, which supports their absence in the Seychelles.

Conclusions: In the granitic islands of the Seychelles, the climate is favourable for anophelines. However, these islands are protected by their remoteness and prevailing seasonal winds. In addition, stagnant freshwater, required in anopheline larval development, is relatively uncommon on the granitic islands because of the steep slopes. In the southwestern atolls (Aldabra and Providence-Farquhar groups), the presence of a long dry season of up to nine months and the total absence of permanent natural freshwater prevents the breeding of anophelines and their successful colonization. The Seychelles does not have any native land mammals and like in other parts of the world (Antarctica, Iceland, New Caledonia, Central Pacific islands) their absence is associated with the lack of anophelines. This suggests an obligatory relationship for anophelines to feed on terrestrial mammals, without alternative for blood-feeding sources, such as bats, birds and reptiles.

\section{Background}

Plasmodium parasites are transmitted by mosquitoes (family Culicidae). Malaria parasites of mammals, including humans, are exclusively transmitted by mosquitoes belonging to the genus Anopheles. These anophelines are observed virtually worldwide, although the distribution of a given Anopheles species varies from being highly localized to sub-continental. For example, on the one hand Anopheles bwambae occurs exclusively within a $10 \mathrm{~km}$ radius of geothermal springs in Bwamba, Uganda, and, on the other hand, Anopheles messeae is

\footnotetext{
* Correspondence: vincent.robert@ird.fr

'MIVEGEC Maladies infectieuses et Vecteurs: Ecologie, Génétique, Evolution et Contrôle (IRD 224, CNRS 5290, Université Montpellier 1, Université Montpellier 2), Centre IRD France-Sud, BP 64501, 911 Avenue Agropolis, 34394 Montpellier cedex 5, France

Full list of author information is available at the end of the article
}

found in most of Eurasia from Ireland to Central Siberia $[1,2]$.

The examples of areas without anophelines are limited and include Antarctica, Iceland, and a heterogeneous set of tropical islands, including the Seychelles, New Caledonia and those in the Central Pacific. In the first two zones, there are simply no mosquitoes, and in the third category there are no anophelines (sub-family Anophelinae), although culicine mosquitoes (sub-family Culicinae) abound. In this list of islands without anophelines, the case of the Seychelles is puzzling for at least two reasons: (i) the Seychelles is located in the southwestern Indian Ocean where most existing islands, if not all, present autochthonous or introduced anophelines (African east coast, Madagascar, the Comoros archipelago, La Réunion, Mauritius); (ii) subequatorial islands in the Seychelles have climatic conditions suitable for

\section{Biomed Central}


anophelines. Consequently, it is difficult to explain the absence of anophelines in the Seychelles [3,4].

\section{An overview of the Seychelles}

The Seychelles is an island state. The archipelago comprises 84,000 inhabitants (2009 census), making it the smallest population of any African state. The total emerged surface area is $455 \mathrm{~km}^{2}$, composed of about 115 main islands located $4^{\circ}$ to $10^{\circ}$ south of the equator. The majority of islands are without any permanent residents. Islands are grouped in several distant archipelagos, which comprise a zone of about 1,400,000 km² (Figure 1). The largest island of Mahé (surface area of $155 \mathrm{~km}^{2}$ ) hosts the capital city, Victoria (26,000 inhabitants), the international airport and the principal harbour. The Seychelles is listed amongst the biodiversity hotspots of the world [5], with high levels of endemism and law protects almost $50 \%$ of the archipelago land surface as nature reserves or national parks. However, there are no native mammals in the Seychelles, with the exception of bats [6,7]. As in most areas of the world, where humans have established themselves, domestic or commensal mammals, such as cattle, dogs, cats, rats and mice, have been introduced.

The archipelago can be divided into two distinct types of islands, based on their geological origin, granitic and coralline. The granitic islands are located in the northeastern part of the Seychelles, about 1,000 km northeast of Madagascar and 1,500 km east of Kenya, and comprise three large islands (Mahé, Praslin and La Digue) on which $99 \%$ of the human population lives. The granitic portions of the Seychelles are the only mid-oceanic granitic islands in the world and are remnants of the break-up of ancient Gondwana supercontinent associated with the splitting of Indo-Madagascar $[8,9]$. These

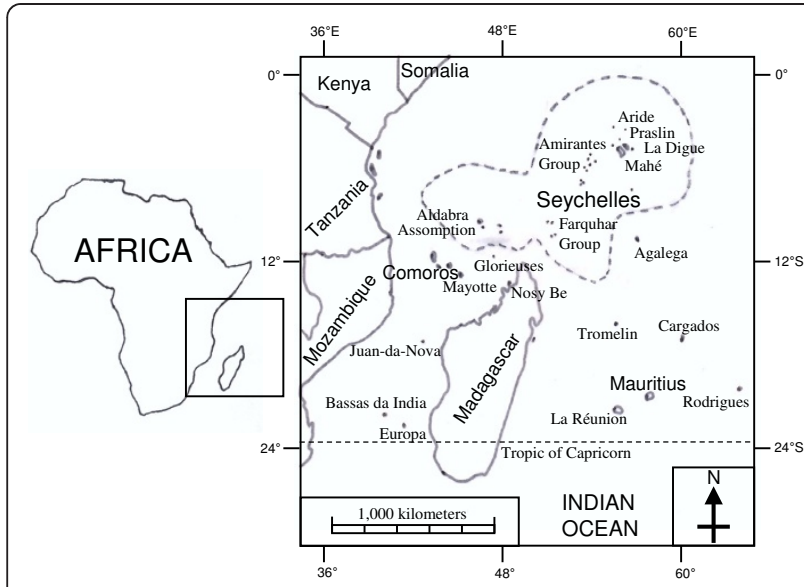

Figure 1 Map of the Seychelles islands. The Seychelles islands and the main neighbouring emerged lands. Dashed line represents the limit of the Seychelles' Exclusive Economic Zone. granitic islands have been separated from other emerged land for c.75 million years. Given their elevation, in geological time these islands were never totally submerged associated with rising sea-levels, although in some cases modern separate landmasses, which rest on a submarine microcontinental plateau, would have been connected during periods of lower sea-level (Figure 2). Mahé has the highest peak in the archipelago, Morne Seychellois at $930 \mathrm{~m}$. This mountain mass holds extensive humid tropical forests dominated by exotic plants, but with relict largely primary forests above $600 \mathrm{~m}$. The Vallée de Mai on Praslin has native forest, composed by a variety of endemic palm trees (Figure 3).

The climate on the granitic islands is very humid $(\geq 80 \%)$ all year round and on Mahé average temperatures vary little throughout the year, from 24 to $30^{\circ} \mathrm{C}$ at sea-level, and annual rainfall ranges from less than $1.9 \mathrm{~m}$ in the south, $2.7 \mathrm{~m}$ at Victoria and over $3.6 \mathrm{~m}$ on the mountain slopes. During the coolest months, July and August, the average temperature drops a few degrees. The hot months, December to April, have maximum temperatures in March and April (up to $34^{\circ} \mathrm{C}$ ). The southeast trade winds blow regularly from May to November. Most of the archipelago lies outside the cyclone belt, so very strong winds are rare.

Coralline islands are situated beyond the Seychelles Plateau and grouped into several archipelagos, the Amirantes group, the Farquhar group and the Aldabra group. They present calcareous substratum on volcanic bedrock and have a maximum elevation above sea-level of a few meters. Consequently, they were totally submerged during marine transgressions, periods that would have eliminated the terrestrial biota. For instance, in recent geological history, Aldabra was completely underwater

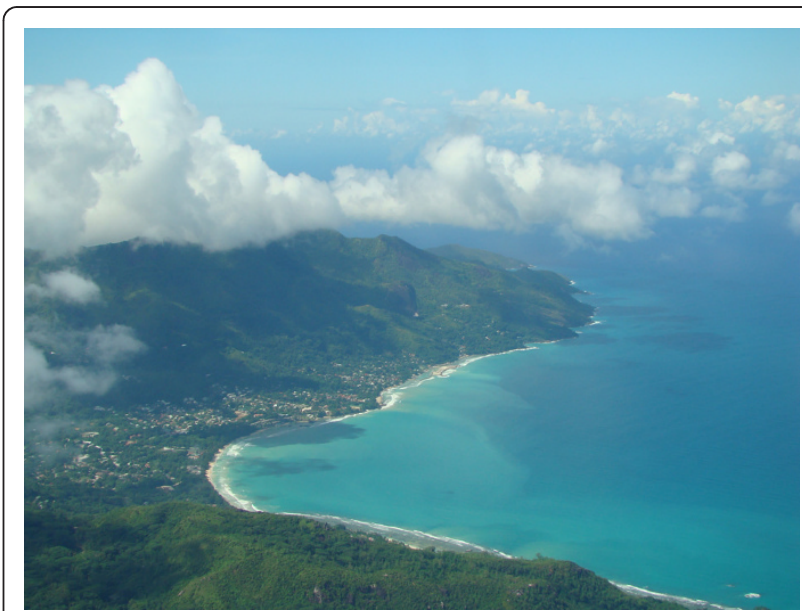

Figure 2 Photo of Mahé, the main granitic island in the Seychelles. Note the important elevational gradient and steep slopes of most of the island. (Photo V. Robert/IRD). 


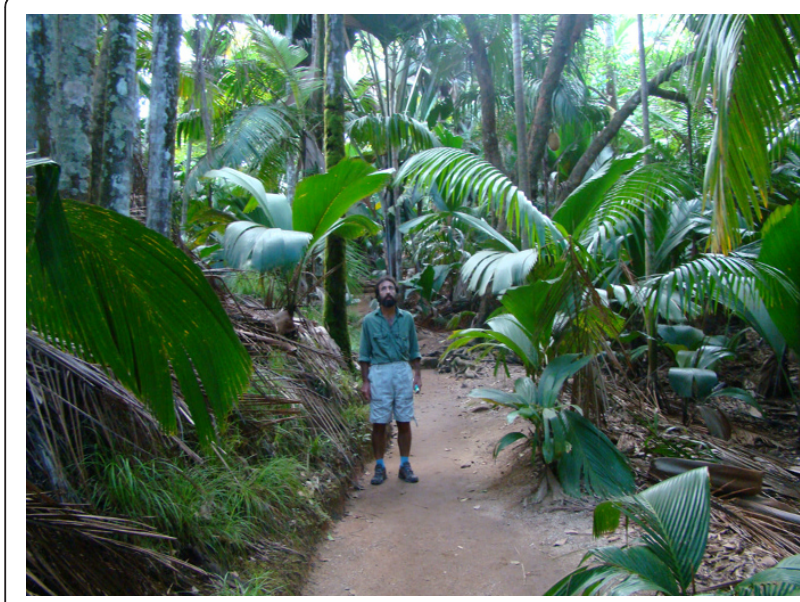

Figure 3 Photo of Vallée de Mai, Praslin Island. Note the flora, composed largely of palm trees. (Photo V. Robert/IRD).

on at least two occasions, with the most recent complete submersion occurring c.125,000 years ago [10-12]. Aldabra is a huge atoll (155 km $\mathrm{km}^{2}$ of emerged land) of $34 \mathrm{~km}$ long, $14.5 \mathrm{~km}$ wide; it consists in raised coral of up to $8 \mathrm{~m}$ above sea level (Figure 4), and comprises 4 main islands enclosing a central lagoon of $224 \mathrm{~km}^{2}$ [13]. The greatest colony in the world of giant tortoises (Testudo gigantea) is found at Aldabra, with up to 150,000 individuals. The avifauna is very diversified for both landbirds and seabirds, the latter being most abundant in the mangroves and islets around the lagoon [14].

The climate of the coralline islands is rather different from the granitic islands. For instance, on Aldabra, from April to October, the trade winds blow from the southeast and carry relatively dry and cool air, with minimal

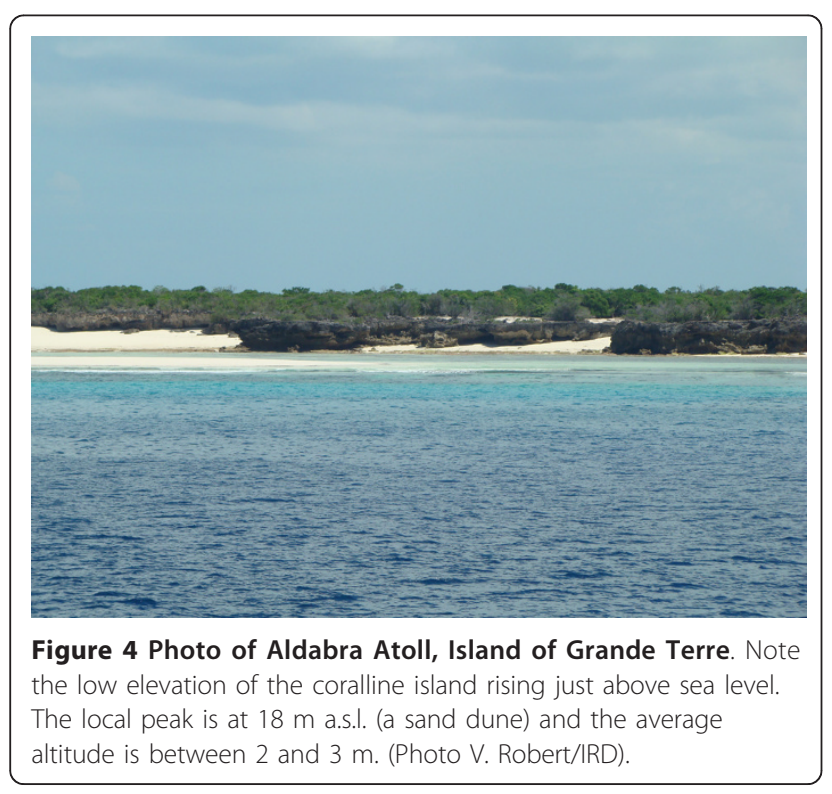

temperatures of $22^{\circ} \mathrm{C}$ in August. From November to March, the monsoon coming from northwest brings higher humidity and temperatures with maximums up to $32^{\circ} \mathrm{C}$ in December. Annual mean temperature is $27^{\circ} \mathrm{C}$. Annual mean recorded rainfall at Aldabra-Picard is $1,100 \mathrm{~mm}$, with ranges varying from 349 to $1,467 \mathrm{~mm}$ during the period 1949-1978.

The islands of Aldabra and Mahé are 1,150 km distant from one another, but the southwestern islands are much closer to neighbouring foreign countries, with Farquhar at c. $290 \mathrm{~km}$ from Madagascar and Aldabra at c. $420 \mathrm{~km}$ equidistant from the Comoros and Madagascar. Assomption Island belongs to the Aldabra group, at some $40 \mathrm{~km}$ south of the Aldabra Atoll, and is nearly $7 \mathrm{~km}$ long and $2.5 \mathrm{~km}$ wide.

\section{Current knowledge on mosquitoes and main associated diseases in the SW Indian Ocean and in the Seychelles} In the southwestern Indian Ocean (SWIO), all the culicidian vectors (but not all mosquitoes) are of exogenous origin. This includes Madagascar where the rich endemic culicidian fauna contains 13 species of anophelines, not a single one being a known vector of malaria parasites (Table 1). In this SWIO area, there is no endemism at the generic level, and all endemic species belong to the genera Culex, Aedes and Anopheles, which have African or Malagasy affinities [15].

Culex quinquefasciatus, a pan-tropical mosquito, is present on all the SWIO islands. It can easily reproduce in the water supply of ships, permitting its introduction by early sailors who crossed the Indian Ocean. Contrarily to continental Africa and on any islands of the SWIO, Cx. quinquefasciatus is considered as the unique potential vector of the lymphatic filariosis Wuchereria bancrofti in the Seychelles, although its transmission capacity is poor [4] and where a dramatic decrease of this transmission has been noted in recent years (S. Julienne, unpublished data).

Table 1 Number of anopheline species per country

\begin{tabular}{lc}
\hline Area & Nb of anopheline species \\
\hline Afrotropical region & 142 \\
Somalia & 20 \\
Kenya & 41 \\
Tanzania & 48 \\
Mozambique & 29 \\
Comoros & 8 \\
Madagascar & 26 \\
La Réunion & 3 \\
Mauritius & 5 \\
Seychelles & 0 \\
\hline
\end{tabular}

Number of anopheline species per geographical area, including countries bordering the southwestern Indian Ocean [Source 61]. 
Aedes aegypti and Aedes albopictus are also mosquitoes that can be easily transported. They reproduce in small amounts of water. Their eggs are resistant to dehydration within receptacles where they are laid and, when re-immersed in water, they successfully hatch. At present, Ae aegypti occupies all the islands of the SWIO, except Mauritius where it was eradicated as a result of a DDT spraying campaign between 1949 and 1951 to control malaria. On Madagascar, it occupies only the western coast. Aedes albopictus is present along the eastern Malagasy coast and on Mauritius. Recently it has been observed for the first time on GrandeGlorieuse (distant of only $135 \mathrm{~km}$ from Astove, in the Aldabra group) and Juan-da-Nova [16]. On La Réunion and the granitic islands of the Seychelles, both Ae. albopictus and $A e$ e aegypti occur, as in many portions of the world with the former being more common [17-20]. In the coralline portions of the Seychelles, only Ae. aegypti is documented. The Seychelles experienced epidemics of dengue II from December 1976 to April 1977 [21,22] and of Chikungunya from March 2005 to late 2007 [23] with Ae. albopictus as the main presumed vector of these diseases.

The case of anophelines is different. Over relatively short distances (up to a few hundred kilometres), adult mosquitoes can be transported by wind. However, most introductions of anopheline mosquitoes over long distances are thought to have occurred via human-aided means, especially accidental transportation on ships and aircrafts. Anopheles species that are efficient vectors of human malaria generally do not produce desiccationresistant eggs, are not autogenous, breed in natural habitats, are not known to undergo diapause and do not reproduce on boats. For all these reasons, they have certain limitations, as compared to Aedes, for transportation across large distances. Anopheles can probably survive no more than ten days without laying eggs, which excludes long distance transport by boat. Indeed, members of this genus invaded Mauritius in 1865, after the commencement of steamer line from Tamatave (Madagascar) to Port Louis, which reduced the duration of the journey of one month to a few days (Table 2). On the other hand, it is unclear how and when anophelines became established on Madagascar and the Comoros. They may have been introduced by early sailors but the possibility of wind dispersion cannot be eliminated; indeed, the natural colonisation by Anopheles arabiensis of La Réunion from Mauritius (about $200 \mathrm{~km}$ away) associated with a cyclone prior to the first malaria outbreak on La Réunion in 1868 is a valuable clue [24,25]. At present, Anopheles gambiae s.s. is known from the Comoros and the eastern coast of Madagascar [26]. Anopheles arabiensis occupies the totality of Madagascar, Mauritius, La Réunion and Grande Glorieuse [27,28].
On Madagascar and the Comoros, except on Grande Comore, Anopheles funestus breeds in rice fields. This species was introduced to Mauritius and perhaps La Réunion, but disappeared during DDT treatments. The granitic islands of the Seychelles, the remote Rodrigues Island and the Chagos archipelago have no known anophelines.

Finally, the culicidian fauna in the Seychelles contains 17 species in four genera (Culex, Aedes, Mansonia and Uranotaenia). Amongst these are two invasive mosquito species, C. tritaeniorhynhus and C. fuscocephallus, introduced to Mahé between 1969 and 1995 [29].

\section{The case of Aldabra}

In the Aldabra group (composed of Aldabra, Assomption, Cosmoledo and Astove), the history of the presence of Anopheles and Plasmodium is complicated. Up until the beginning of the $20^{\text {th }}$ century, the island group had been unambiguously considered as safe with regards to malaria transmission. In March 1908, the first malaria outbreak of benign tertian type occurred on the Aldabra Atoll. The disease was confined to the settlement on Picard Island and started 11 days after the arrival of a boat from Nosy-Be (Madagascar) and with Malagasy passengers suffering from malaria. The number of infected humans gradually increased with a peak in JulyAugust of that same year, but a progressive diminution in severity was noticed, the earlier cases being the more severe. The last incident was observed at the end of September 1908. In total, 98 cases were recorded, all treated by quinine [30]. Even though no specific research was conducted on mosquito larvae, by midSeptember, the oiling of all water pools and puddles was performed on the atoll [31]. On the basis of fieldwork conducted by several eminent entomologists from October 1908 to January 1909 [JCF Fryer, 1910 in 30], no evidence of adult or larval Anopheles was detected.

After a lapse of two decades, a second malaria outbreak, this time due to Plasmodium falciparum imported via workers who were previously on Mauritius and Juan-da-Nova, occurred with a first phase on Assomption (June to October 1930) and a second phase on Aldabra (October 1930 to January 1931). It is an established fact that this outbreak was transmitted by a species of the Anopheles gambiae complex (named costalis at that time). During the epidemic, huge densities of this mosquito were observed at adult and larval stages on Picard Island, but not documented on other islands of the atoll. Vector control targeting larvae was performed on 31 January 1931 using 'Paris green oil' (an insecticide routinely used at that time), poured into 966 pools of water in the neighbourhood of the Picard Island settlement, among which 281 had anopheline larvae. Anophelines were not documented on Assomption 
Table 2 Well-documented introductions of anopheline species in the southwestern Indian Ocean

\begin{tabular}{|c|c|c|c|}
\hline Date & Location & Anopheline & Main reference \\
\hline 1865 & Mauritius & An. gambiae s.l. & [24] \\
\hline 1867 & La Réunion & An. arabiensis & [24] \\
\hline Before 1900 & Mauritius & An. coustani & {$[62]$} \\
\hline Before 1900 & Mauritius & An. maculipalpis & {$[62]$} \\
\hline Before 1902 & La Réunion & An. coustani & [63] \\
\hline 1908 & Aldabra (Seychelles) & An. gambiae s.l. & {$[30]$} \\
\hline 1930 & Aldabra and Assomption (Seychelles) & An. gambiae s.l. & {$[30]$} \\
\hline Before 1932 & Mauritius & An. funestus & [24] \\
\hline 1949 & La Réunion & An. funestus & [24] \\
\hline Before 1975 & Mauritius & An. arabiensis & {$[27]$} \\
\hline 1975 & Assomption (Seychelles) & An. gambiae s.l. & {$[32]$} \\
\hline 2002 & Grande-Glorieuse (France) & An. arabiensis & {$[28]$} \\
\hline
\end{tabular}

from the end of 1930, but still remained somewhat numerous on Picard, despite the insecticide treatment, until April 1931 [30]. These malaria cases were the last autochthonous ones recorded in the Seychelles.

These introductions of anophelines in the Aldabra group were apparently not followed by successful continuation of local populations over the following dry season. It has been questioned if An. gambiae s.l. can survive on Aldabra during the extended dry season at sufficient densities to cause subsequent malaria outbreaks, perhaps feeding on numerous wild goats. Presumably, the lack of freshwater pools on the island during the dry season results in the crash and extirpation of local populations. Hence, each malaria outbreak is associated with an independent colonization event of the vector mosquito.

The last point to mention is the observation of $A n$. gambiae s.l. on Assomption Island in 1975 [32]. This record must be interpreted with caution because complementary field surveys during the same period did not find additional evidence of anophelines on the island. The 1975 record of this mosquito on the island may have been due to materials that were previously used for training courses in continental Africa, resulting in accidental pipette contamination (S. Julienne, unpublished data).

Trying to explain why anopheline mosquitoes are not present in the Seychelles is difficult to answer. As a prerequisite, in order to provide insight into the dynamics of mosquito species richness and colonization/extinction patterns in the Seychelles, particularly for anophelines, a field survey of several different granitic and coralline islands was conducted, the results of which are presented here.

\section{Methods}

A field survey was conducted in the Seychelles from 29 November to 18 December 2008, during the rainy season, a period a priori favourable to detect anophelines, if present. The islands chosen for survey were based on the following rationale. Four granitic islands were selected, including the three most populated (Mahé, Praslin, La Digue) and a small granitic island (Aride), the latter with only a handful of permanent human residents and over a million birds. Four coralline islands belonging to the Aldabra group were selected (Picard, Malabar and Grande Terre within the Aldabra Atoll, plus neighbouring Assomption). Emphasis was placed on these latter islands based on knowledge of previous anophelines introductions during the $20^{\text {th }}$ century. The list of visited islands and precise details of sampled sites are presented in Table 3.

Entomological survey methods included: (i) Immature stages (larvae and pupae) - detailed examination for immature stages was performed at natural and humanmade water collection sites, including marshes, tree holes, crab holes in mangroves, containers and reservoirs (Figure 5); (ii) Adult mosquitoes - using CDC Miniature Light Trap 6 volts (BioQuip ${ }^{\mathrm{TM}}$ ) from dusk to dawn, with a 4-watt incandescent light and a 4-watt black light tube (UV light ca. 320-420 nm). CDC traps were placed outdoors and used without olfactory attractant such as $\mathrm{CO}_{2}$ or next to human/animal bait. Systematic collection of mosquitoes on humans was not conducted, although alighting mosquitoes on members of the field team were collected. Netting of insects resting on vegetation was conducted only on Mahé, with few captures and these are not reported on herein.

\section{Results}

Granitic islands (Mahé, Praslin, La Digue and Aride)

The number of sites with collection of adult and immature mosquitoes was 17 and 16, respectively. Forty-eight trap-nights were accrued, and total numbers of mosquitoes collected by traps and landing on humans were 612 and 16 , respectively. In the context of pre-imaginal surveys, efforts concentrated on possible unknown endemic 
Table 3 Principal results of the 2008 entomological survey for adult Culicinae mosquitoes in the Seychelles

\begin{tabular}{|c|c|c|c|c|}
\hline Date & $\begin{array}{l}\text { Island } \\
\text { type }\end{array}$ & $\begin{array}{l}\text { Island and locations for CDC light-trap (and } \\
\mathrm{Nb} \text { of night-trap) }\end{array}$ & $\begin{array}{l}\mathrm{Nb} \text { of adult } \\
\text { Culicinae }\end{array}$ & Locations for larval sampling effort \\
\hline Nov 29 & Granitic & Mahé $\left(145 \mathrm{~km}^{2}\right)$ & & Marre aux cochons \\
\hline \multirow[t]{3}{*}{ Nov 30} & & Victoria (2) & 3 & Tea plantation, Morne Blanc, Copolia \\
\hline & & Copolia (6) & 4 & Tea plantation \\
\hline & & Aride $\left(0.7 \mathrm{~km}^{2}\right)$ & & \\
\hline \multirow[t]{2}{*}{ Dec 2} & & Plateau and summit (6) & 5 & Plateau, summit \\
\hline & & Praslin $\left(38 \mathrm{~km}^{2}\right)$ & & \\
\hline Dec 3 & & Anse Kerlan (6) & 191 & Grande Anse \\
\hline \multirow[t]{2}{*}{ Dec 4} & & $\begin{array}{l}\text { Vallée de Mai (3), Fond B'Offay (1), Grande Anse } \\
\text { (1) }\end{array}$ & $41+1+30$ & $\begin{array}{l}\text { Vallée de Mai, Baie Sainte-Anne, Marie Jeanne, Côte } \\
\text { d'Or, Anse Boudin }\end{array}$ \\
\hline & & La Digue $\left(10 \mathrm{~km}^{2}\right)$ & & \\
\hline Dec 5 & & La Passe (4), La Veuve Reserve (2) & $23+48$ & La Passe, La Veuve Reserve \\
\hline \multirow[t]{2}{*}{ Dec 6} & & L'Union (4), Pointe Source d'Argent (2) & $57+11$ & L'Union, Pointe Source d'Argent \\
\hline & & Mahé & & \\
\hline Dec 7 & & Petit Paris (2) & 5 & \\
\hline Dec 8 & & Anse Intendance (2), Baie Police (2) & $46+130$ & \\
\hline Dec 9 & & Baie Lazare (2), Port Launay (2) & $15+2$ & \\
\hline \multirow{2}{*}{$\begin{array}{l}\text { Total granitic } \\
\text { islands }\end{array}$} & & 4 islands; 17 sites (48) & 612 mosq & 16 sites \\
\hline & Coralline & Aldabra - Picard $\left(9 \mathrm{~km}^{2}\right)$ & & \\
\hline \multirow[t]{2}{*}{ Dec 12} & & Research station (5) & 19 & Research station \\
\hline & & Aldabra - Malabar $\left(27 \mathrm{~km}^{2}\right)$ & & \\
\hline \multirow[t]{2}{*}{ Dec 13} & & Middle camp (4) & 130 & Middle camp \\
\hline & & Aldabra - Grande Terre $\left(116 \mathrm{~km}^{2}\right)$ & & \\
\hline Dec 14 & & Takamaka grove (4) & 1,154 & Takamaka \\
\hline Dec 15 & & Cinq Cases $(1+3)$ & $8,750^{*}+1,800$ & Cinq Cases \\
\hline \multirow[t]{2}{*}{ Dec 16} & & Anse Maïs (3) & 307 & Anse Maïs \\
\hline & & Aldabra - Picard & & \\
\hline \multirow[t]{2}{*}{ Dec 17} & & $\begin{array}{l}\text { Jelly Fish Pound (1), Bassin Livine (1), Passe } \\
\text { Femme (2) }\end{array}$ & $10+0+22$ & Jelly Fish Pound, Bassin Livine \\
\hline & & Assomption $\left(11 \mathrm{~km}^{2}\right)$ & & \\
\hline Dec 18 & & Port (1), airport (3) & $2,770^{*}+104$ & Port; airport \\
\hline $\begin{array}{l}\text { Total coralline } \\
\text { islands }\end{array}$ & & 4 islands; 10 sites (28) & 15,066 mosq & 9 sites \\
\hline Grand total & & 8 islands; 27 sites (76) & 15,678 mosq & 25 sites \\
\hline
\end{tabular}

species of anopheline in the Mahé mountains, particularly larval stages living in small streams. This type of ecological setting on Madagascar is often occupied by endemic anophelines [33]. No evidence of anophelines was found on the granitic islands during these surveys (Table 3).

\section{Coralline islands (Picard, Malabar, Grande Terre and Assomption)}

The number of sites with collection of adult and immature mosquitoes was 10 and 9, respectively. Twentyeight trap-nights were accrued, and total numbers of mosquitoes collected by traps and landing on humans were 15,066 and 23 , respectively. No anopheline was obtained on coralline islands.

\section{Discussion}

Despite the effort of prominent entomologists $[3,17,34,35]$ and the November to December 2009 field surveys, introduced and native anophelines have not been documented on the granitic islands. Malaria vectors are believed to never have existed on the granitic islands of the Seychelles and no recent evidence has been found of them on the coralline islands. This has important bearing for public health and the sector of the local economy depending on tourism.

\section{Hypothesis to explain the absence of anophelines in the Seychelles}

The absence of anophelines in the Seychelles is surprising given that the climate is favourable for these 


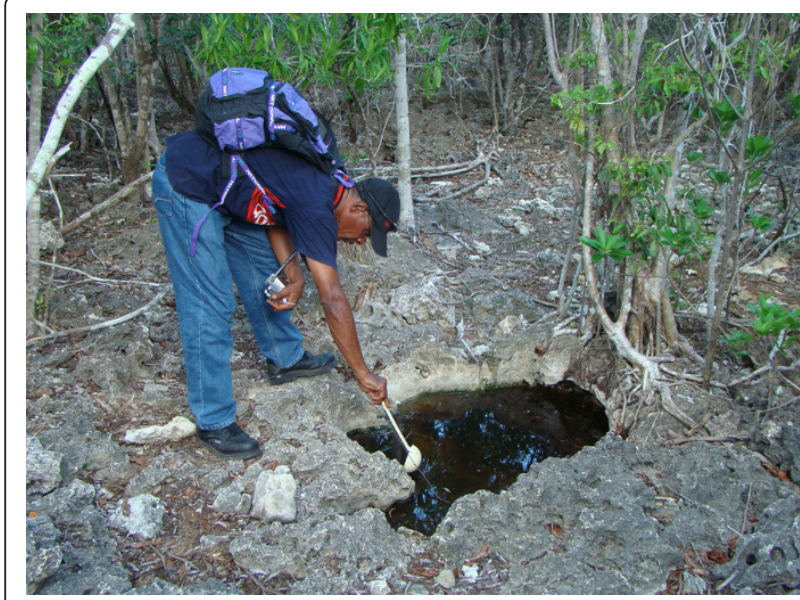

Figure 5 Photo of mosquito larvae collection, Aldabra Atoll, Picard Island. Note the larval breeding places are mainly natural and composed of coral rock pools inundated by rainwater. (Photo V. Robert/IRD)

mosquitoes at least on the granitic islands and to a lesser extent in the Amirantes archipelago. Two hypotheses can explain this absence of anophelines: (i) no natural colonization or introduction, and (ii) introduction did not result in the establishment of a viable breeding population.

Health control procedures currently in place in the archipelago at the few main points of entry have certainly reduced the possibility of successful introduction of mosquitoes, although this is difficult to quantify. For example, it is compulsory for all in-coming flights to the Seychelles to have the cabin sprayed with insecticide. Active control procedures by both customs and public health officers are in place in Victoria (Mahé) at the only international airport in the country and the port. Further, all boats arriving from outside of the country and their cargos are systematically inspected and a health certificate subsequently delivered. In certain cases, fumigation of containers and the complete vessel may be required. A programme aiming at developing biosecurity measures, including training and improvement of enforcement, is currently being implemented as part of a GEF Biosecurity Project. The Seychelles are an important tourist destination with over 150,000 individuals arriving per year (estimation for 2007); three quarters of them being Europeans [23]. With the exclusion of the Victoria port, most of the harbours in the country are small, mainly devoted to local fisheries and national commerce. The majority of international flights provide connections to Europe and the Middle East, with few connections to continental Africa and Asia. The dozen or so destinations served by Air Seychelles, the national company and main passenger carrier, includes countries without endemic malaria (Paris, Moscow, Singapore,
Johannesburg, etc.), although flights to India (Mumbai, Chennai) are planned to commence in the near future. There has been no report of 'airport malaria'. It is hard to certify that the preventive measures installed by health authorities at the international airport and port are completely efficient, but it is reasonable to maintain these measures. The number of cruise ships coming directly to the Seychelles from Madagascar or Mayotte, both islands with endemic malaria, has been increasing over the last 15 years, at least until the recent decline due to piracy, and a procedure of fumigation of these vessels comparable to the system used for aircrafts may be advisable, especially when the vessels stay at quay.

Several authors have previously alerted to the dangers that Mahé and the other granitic islands harbour introduced anophelines $[3,17,34,36]$. From an ecological point of view, this seems perfectly possible in the few marshy zones present on these islands.

Dispersal of mosquitoes can occur either naturally (by active flight or passive dispersal) or mediated by human activities (transportation by land, air or water). The possibility of natural dispersion by wind currents exists from continental Africa, Comoros and Madagascar, especially on the coralline southwestern islands. As previously noted, this mean of dispersal had been suspected for An. gambiae on Comoros and Madagascar and for $A n$. arabiensis on La Réunion. The African vector $A n$. arabiensis was introduced in Natal, Brazil, in 1930. Larvae or adult mosquitoes are believed to have travelled by air or more probably by steamer ship from Dakar, Senegal. This introduction had a major importance as a malaria vector with higher vectorial capacity than the autochthonous anopheline species, causing malaria outbreaks in 1930-1931 and a devastating epidemic in 1938-1939 across much of northeastern Brazil, especially along river courses [37]. This is only one example, among many, of important mosquito invasions that have taken place across the globe [see [38,39]].

Once an introduction has taken place, several different factors come into play for successful establishment of viable breeding populations, such as adaptation to the new environment and ability to cope with predators and competitors. For anophelines, several undocumented introduction events might have occurred on the granitic islands of the Seychelles, as has been evidenced in the Aldabra group. It is important to note that in the latter case these events have not lead to successful colonization with permanent breeding populations. Excluding the case of chemical treatment, unfavourable environmental conditions during the long dry season is a critical aspect that does not allow anophelines to complete properly the breeding cycle. This in turn demonstrates certain constraints for these introduced animals to adapt to notably different ecological conditions. A case in 
point is that an $A n$. arabiensis population was found in March 2002 on Grande Glorieuse [28], but was absent by April 2008 [20].

\section{The question of endemic anophelines in the Seychelles (local speciation)}

Beside the aspect of the introduction and subsequent establishment of anophelines in the Seychelles, remains the question of the absence of native anophelines. Given that the granitic islands have not been submerged since deep in geological time, it is biogeographically plausible for endemic anophelines to exist in this portion of the archipelago. Many of the small mountain streams, for example on Mahé, show climatological and topographical parallels to places on Madagascar with endemic anophelines; such sites are ideal for the development of the larval stages of these mosquitoes. While seemingly anomalous, no endemic anopheline has been documented in the Seychelles [see Results and [34]]. Endemic species of mosquitoes exist in the Seychelles, belonging to the genera Culex, Aedes and Uranotaenia [35].

Does the present day biota on the granitic islands represent the continental species that remained on the islands after continental drifting? Conversely, did a previous radiation of anophelines occur on these islands, followed by complete extinction? These questions remain open. But it is noteworthy that the divergence time for the major culicid lineages (Anophelinae vs. Culicinae) date to the early Cretaceous, 217 million years ago (CI: 229.50 - 192.19) [40], at a time much prior to the breakup of the ancient Gondwana supercontinent and the subsequent splitting of IndoMadagascar and the deposition of the granitic islands of the Seychelles, some 75 million years ago $[8,9]$.

On the Aldabra Atoll, insect diversity is estimated to exceed 1,000 species, of which a minimum of $23 \%$ are endemic (38\% in the Aldabra group), and mainly derived from Malagasy lineages [41,42]. Given the complete submersion of the atolls by rising sea-levels over the past 125,000 years, this level of endemism amongst invertebrates is considerable, and illustrates the rapid differentiation and speciation processes taking place at Aldabra [e.g., $[43,44]]$.

\section{Biogeography of zones without anopheline mosquitoes} In order to understand why no native anophelines occur in the Seychelles, it is worthwhile to examine other areas of the world also lacking these mosquitoes, which are notably limited to: Antarctica, Iceland, and a heterogeneous set of tropical islands, namely the Seychelles, New Caledonia and islands in the Central Pacific. In the two first areas, mosquitoes are completely lacking and in the third area, there are no Anophelinae although the Culicinae are present.
The absence of anophelines on Antarctica is easy to explain. Antarctica is the coldest place on Earth and due to the harsh climatic conditions, insects are scarce and less than 100 species of insects have been recorded [45]. Most of these are ectoparasites, like lice, which live in the feathers of birds and the fur of seals. Three species of chironomid midges (Diptera) and some springtails (Collembola) are the only free-living insects known from Antarctica. As a corollary to this point, there are no native terrestrial mammals on Antarctica.

There is also no mosquito known from Iceland, although these insects are common in portions of the world at the same latitude, such as northern Canada, Greenland and Scandinavia. There are two species of Culicinae on Greenland (Aedes nigripes and Aedes impiger), one on Svalbard and the Jan Mayen islands ( $A e$. nigripes), and 28 in Norway (including Anopheles claviger, An. messeae and Ae. nigripes). The reason why mosquitoes, especially Ae. nigripes, have not colonized Iceland may be due to variable climatic conditions on the island, with sudden temperature increases in the middle of winter that disturb hibernating pupal stage beneath ice, activating hatching of eggs into adult mosquitoes as soon as the ice melts. Adult mosquitoes suffer considerable mortality with subsequent drops in temperature [46]. There are also no mosquitoes on the Faroe and Shetland Islands where the climate is notably milder during the winter (mean temperature $3.5^{\circ} \mathrm{C}$ on the Faroes) than on Iceland [47-49]. These two islands lie in the path of strong northeast winds that are common throughout the year. With the exception of the arctic fox on Iceland, no species of native terrestrial mammal is known from these islands.

In New Caledonia, located in the western Pacific, about 20 species of mosquitoes have been recorded in the genera Culex, Aedes, Mansonia and Tripteroides, but anophelines are unknown [50]. This observation is noteworthy, as New Caledonia is peripheral to the distribution of the major malaria vector Anopheles farauti (Australia, Papua-New Guinea and Vanuatu) [2]. The absence of $A n$. farauti on New Caledonia may be related with the island being just south of a line drawn between the two southern most localities, Australia and Vanuatu, in which $A n$. farauti has been collected. The difference in latitude implies colder temperatures (average temperature at sea level in Vanuatu ranges between $24^{\circ}$ and $26^{\circ} \mathrm{C}$ versus $22^{\circ}$ and $24^{\circ} \mathrm{C}$ on New Caledonia). In addition, the unique geological nature of soils on the main island of New Caledonia, mostly ferralitic or ferritic soils overlaying ultrabasic rock, might be toxic for mosquitoes at larval stages and, therefore, helps to explain the local absence of anopheline mosquitoes. However, Laird [51] mentioned that An. farauti and Anopheles sundaicus (a malaria vector in Indonesia and in the Malaysian 
Peninsula) may find suitable larval breeding places on New Caledonia.

The islands in the central Pacific with few or no native mosquitoes and a high volume of commercial or military air and maritime traffic are particularly vulnerable to mosquito invasions [38]. Having said this, no anopheline is known from these islands. In Polynesia, 43 species of mosquitoes are recorded, belonging to 7 genera [52], but the genus Anopheles is absent. In the Hawaiian archipelago, mosquitoes were unknown until 1826, when a whaling ship introduced $C x$. quinquefasciatus. In 2004, Aedes japonicus japonicus was found to be established and widespread on the windward island of Hawaii, elevating the number of mosquito species in the island group to 8 [53]. The introduction of mosquitoes and subsequent spread of avian malaria, Plasmodium relictum, brought in with exotic birds had disastrous consequences for the native birds of Hawaii, and is considered responsible for the extinction or severe decline of several species [54,55]. In 2003, Anopheles punctipennis, a former human malaria vector in North America, was detected on Honolulu but did not establish permanent breeding populations. State quarantine officers in Hawaii have intercepted more than 40 different species of mosquitoes [56]. No terrestrial mammal species occurs in the tropical Pacific islands (including New Caledonia) to the east of the Solomons and west of the Galapagos [57].

\section{Anophelines and terrestrial mammals}

Interestingly, and apparently not previously mentioned in the literature, areas without anopheline species have no native terrestrial mammals. ('Native' and 'terrestrial' are here defined as 'not artificially introduced' and 'non-flying or sea-dwelling', respectively). Anophelines prefer mammals when they are searching for blood meals and indeed, they feed almost entirely on mammals, with an extensive feeding range among mammals depending on their respective availability [58]. Consequently, only a small percentage, less than $1 \%$, of vertebrate blood meals by many Anopheles species are from birds or other non-mammalian vertebrates [59]. Observations from our late 2008 fieldwork are in agreement with this general feature, and there appears to be an obligatory relationship for anophelines to feed on terrestrial mammals. Hence, when terrestrial mammals are lacking, anophelines have apparently some behavioural, physiological or metabolic constraints in the use of blood from other terrestrial vertebrates (birds and reptiles) in their reproductive cycle.

As far as can be determined, it is notably rare for bats to be the main source of blood for some very peculiar anophelines; the species Anopheles hamoni that lives at all stages in the deepest part of a small number of caves in the Congo feeds mostly on microchiroptera bats [60].

\section{Conclusions}

Any attempt to explain the absence of anophelines in the Seychelles archipelago is inherently speculative. However, the resolution of this question is an interesting and important biogeographic challenge linked with a number of theoretical and applied biological aspects associated with invasive species, specifically the debate of adaptation $v s$. evolution and the aspect of elimination-eradication of natural populations by man.

Biological characteristics of Anopheles vectors of human malaria, such as the eggs being susceptible to desiccation, lack of autogeny, preference for natural breeding sites and absence of diapauses, make them relatively inefficient colonizers. However, successful introductions of An. gambiae s.l. occurred in the southwestern islands of the Seychelles during the $20^{\text {th }}$ century. Taking into account the importance of the maritime and aerial traffic through the international shipping port and the airport in Victoria, it is highly likely that anophelines have been introduced to the granitic islands, but were unable to establish viable breeding populations. The case of the Seychelles confirms that although they are frequently introduced into non-native areas, and contrarily to mosquitoes belonging to the genera Aedes and Culex, most introduced anophelines fail to establish permanently. Furthermore, it needs to be underlined that the granitic portions of the Seychelles are also protected by their isolation, remoteness and by head winds mainly blowing from the southeast during a good portion of the year.

Anophelines are well known to feed almost entirely on mammals. The absence of native terrestrial mammals in the few areas of the world that do not harbour anophelines strongly suggests a strict relationship. Apparently bats, even when present, such as on Aldabra, cannot constitute a replacement host to feed on when terrestrial mammals are not available.

\section{Consent}

Written informed consent for publication was obtained from all individuals within the accompanying images.

\section{Acknowledgements}

This study has been funded by the Programme Institut Français de la biodiversité/CNRS/AIRD 'Biodiversité dans les îles de l'Océan Indien' as part of the regional project 'Insectes vecteurs (phlébotomes et moustiques)'. We thank Mary Stavens, Andrew Jean-Louis and Gaëtan Galman from the Island Conservation Society (ICS) Head Office and the Fond Français pour l'Environnement Mondial project Réhabilitation des Ecosystèmes Insulaires for their help with office space, transportation and equipment on Mahé; Sally Mills and Melvyn Yeandle (ICS) for their help on Aride; the Islands Development Company staff for their help with plane transportation to Assomption; Dr Frauke Fleischer-Dogley and Lindsay Chong Seng from the Seychelles Islands Foundation (SIF) for facilitating our research in the Vallée de Mai and on Aldabra; Naomi Doak, Marc Jean-Baptiste and other SIF/ Aldadra Research Station staff for their help; Peter Holland, Captain Francis 
Roucou and the crew of the Indian Ocean Explorer, our 'base camp' on Assomption and Aldabra, which was attacked and sunk by pirates off the coast of Somalia in March-June 2009; Pat Matyot for bibliographic aid and stimulating discussions; and the Ministry of Environment, Natural Resources and Transport, Division of Nature Conservation for issuing permits to conduct faunistic surveys in the Seychelles. We also wish to thank Dr Jude Gédéon, Principal Secretary of the Ministry of Health of the Seychelles, and Guy Christophe and Gilles Pommeret from the French Embassy in the Seychelles for providing support.

\section{Author details}

'MIVEGEC Maladies infectieuses et Vecteurs: Ecologie, Génétique, Evolution et Contrôle (IRD 224, CNRS 5290, Université Montpellier 1, Université Montpellier 2), Centre IRD France-Sud, BP 64501, 911 Avenue Agropolis, 34394 Montpellier cedex 5, France. 'Island Conservation Society, PO Box 775, Pointe Larue, Mahé, Seychelles. ${ }^{3}$ Ministry of Health, Victoria, Mahé, Seychelles. ${ }^{4}$ Field Museum of Natural History, 1400 South Lake Shore Drive, Chicago, Illinois 60605, USA and Vahatra, BP 3972, Antananarivo 101, Madagascar.

\section{Authors' contributions}

VR, GR, SM and SMG conceived the study, made the field survey and wrote the paper. All authors read and approved the final manuscript.

\section{Competing interests}

The authors declare that they have no competing interests.

Received: 18 November 2010 Accepted: 8 February 2011 Published: 8 February 2011

\section{References}

1. Carnevale P, Robert V, Manguin S, Corbel V, Fontenille D, Garros C, Rogier C: Les anophèles - Biologie, transmission du Plasmodium et lutte antivectorielle Marseille: IRD Ed; 2009, 391.

2. Hay SI, Sinka ME, Okara RM, Kabaria CW, Mbithi PM, Tago CC, Benz D, Gething PW, Howes RE, Patil AP, Temperley WH, Bangs MJ, Chareonviriyaphap T, Elyazar IR, Harbach RE, Hemingway J, Manguin S, Mbogo CM, Rubio-Palis Y, Godfray HC: Developing global maps of the dominant anopheles vectors of human malaria. PLoS Med 2010, 7 e1000209.

3. Mattingly PF, Brown ES: The mosquitos (Diptera: Culicidae) of the Seychelles. Bull Entomol Res 1955, 46:69-110.

4. Lambrecht FL: Filariasis in the Seychelles islands and in the British Indian Ocean territories. WHO/FILMP/73.3 1973, 10.

5. Sechrest W, Brooks TM, da Fonseca GA, Konstant WR, Mittermeier RA Purvis A, Rylands AB, Gittleman JL: Hotspots and the conservation of evolutionary history. Proc Natl Acad Sci USA 2002, 99:2067-2071.

6. Goodman SM, Gerlach J: Chiroptera. In Terrestrial and freshwater vertebrates of the Seychelles Islands. Edited by: Gerlach J. Leiden: Backhuys Publishers; 2007:105-109.

7. Goodman SM, Buccas W, Naidoo T, Ratrimomanarivo F, Taylor PJ, Lamb J: Patterns of morphological and genetic variation in western Indian Ocean members of the Chaerephon 'pumilus' complex (Chiroptera: Molossidae), with the description of a new species from Madagascar. Zootaxa 2010, 2551:1-36.

8. Stoddart DR, (ed.): Biogeography and Ecology of the Seychelles Islands The Hague: Dr W. Junk Publishers; 1984, 691.

9. Wells NA: Some hypothesis on the mesozoic and cenozoic paleoenvironmental history of Madagascar. In The natural history of Madagascar. Edited by: Goodman SM, Benstead JP. Chicago: The Univ of Chicago Press; 2003:16-34.

10. Thomson J, Walton A: Redetermination of the chronology of Aldabra Atoll by Th/U dating. Nature 1972, 240:145-146.

11. Taylor JD, Braithwaite CJR, Peake JF, Arnold EN: Terrestrial faunas and habitats of Aldabra during the late Pleistocene. Phil Trans Roy Soc London. Ser B, Biol SC 1979, 286:47-66.

12. Siddall M, Rohling EJ, Almogi-Labin A, Hemleben C, Meischner D, Schmelzer I, Smeed DA: Sea-level fluctuations during the last glacial cycle. Nature 2003, 423:853-858

13. Stoddart DR, Wright CA: Geography and ecology of Aldabra Atoll. Atoll Res Bull 1967, 118:11-52.
14. Rocamora G, Skerrett A: Seychelles. In IBAs in Africa and associated islands. Edited by: Fishpool L, Evans Ml. Cambridge, Pisces Publications 2001:751-768.

15. Julvez J, Mouchet J: Le peuplement culicidien des îles du sud-ouest de I'Océan Indien. L'action de I'homme dans l'importation des espèces d'intérêt médical. Ann Soc Entomol France (NS) 1994, 30:391-401.

16. Bagny L, Delatte $\mathrm{H}$, Quilici S, Fontenille D: Progressive decrease in Aedes aegypti distribution in Reunion Island since the 1900s. J Med Entomol 2009, 46:1541-1545.

17. Bin F, Laporte $T$, Julienne S: Mosquito larval density survey on Mahé in 1995. Seychelles Medical \& Dental Journal 1996, 4:21-23.

18. Braks MAH, Honório NA, Lounibos LP, Lourenço-De-Oliveira R, Juliano SA: Interspecific competition between two invasive species of container mosquitoes, Aedes aegypti and Aedes albopictus (Diptera: Culicidae), in Brazil. Ann Entomol Soc Amer 2004, 97:130-139.

19. Simard F, Nchoutpouen E, Toto JC, Fontenille D: Geographic distribution and breeding site preference of Aedes albopictus and Aedes aegypti (Diptera: Culicidae) in Cameroon, Central Africa. J Med Entomol 2005, 42:726-731.

20. Bagny L, Freulon M, Delatte $\mathrm{H}$ : Première mention d'Aedes albopictus, vecteur d'arbovirus, dans les îles Eparses du Canal du Mozambique et actualisation de l'inventaire de la faune culicidienne. Bull Soc Path Exot 2009, 102:192-198.

21. Calisher CH, Nuti M, Lazuick JS, Ferrari JDM, Kappus KD: Dengue in the Seychelles. Bull World Health Organ 1981, 59:619-622.

22. Metselaar D, Grainger CR, Oei KC, Reynolds DG, Pudney M, Leake CJ, Tukei PM, D'Offay RM, Simpson DIH: An outbreak of type 2 Dengue fever in the Seychelles probably transmitted by Aedes albopictus (Skuse). Bull World Health Organ 1980, 58:937-943.

23. Taglioni F: Virus-sans-frontières: le chikungunya dans le sud-ouest de I'océan Indien. In Frontières et santé. Genèses et maillages des réseaux transfrontaliers. Edited by: Moullé F. Paris, L'Harmattan; 2009:257-275.

24. Julvez J, Mouchet J, Ragavoodo C: Epidémiologie historique du paludisme dans l'archipel des Mascareignes (océan Indien). Ann belge Méd Trop 1990, 70:249-261

25. Julvez J, Ragavoodoo C, Gopaul AR, Mouchet J: Maladies humaines transmises par les Culicidés dans les îles du sud-ouest de l'océan Indien. Bull Soc Pathol Exot 1998, 91:99-103.

26. Léong Pock Tsy JM, Duchemin JB, Marrama L, Rabarison P, Le Goff G, Rajaonarivelo $\mathrm{V}$, Robert $\mathrm{V}$ : Distribution of the species of the Anopheles gambiae complex and first evidence of Anopheles merus as a malaria vector in Madagascar. Malar J 2003, 2:33.

27. Gopaul AR, Konfortion P: Roof top breeding of Anopheles arabiensis and spread of malaria in Mauritius. Maurice Inst Bull 1988, 10:2-12.

28. Girod R, Le Goff G: Inventaire actualisé des moustiques (Diptera: Culicidae) des îlots français de Europa, Juan-de-Nova et Glorieuse (Canal du Mozambique, océan Indien). Bull Soc Path Exot 2006, 99:122-128.

29. Bin F: New mosquitoes in Seychelles. Seychelles Medical \& Dental Journal 1995, 1:6-7.

30. Hermitte LCD: Occurrence of Anopheles gambiae (costalis) in Aldabra islands (Seychelles). Records of the Malaria Survey of India 1931, 2:643-654

31. Mathew KC, Bradley JT: Research work on an outbreak of malaria at Assumption and Aldabra Islands in 1930 Victoria, Mahé-Seychelles: Government Printing Office; 1932, 14.

32. Bruce-Chwatt LJ: Malaria threat to the Seychelles. Brit Med J 1976, 2:754-755.

33. Grjebine A: Insectes Diptères Culicidae Anophelinae. In Faune de Madagascar. Volume 22. Paris: ORSTOM/CNRS; 1966:487.

34. Lambrecht FL: Notes on the ecology of Seychelles mosquitoes. Bull Entomol Res 1971, 60:513-532.

35. Gerberg EJ, Arnett RH: A pictorial key to the mosquito larvae of the Seychelles. Mosq Syst 1976, 8:343-346

36. Harper JO: A mosquito survey of Mahé, Seychelles. East Afr Med J 1947, 24:25-29.

37. Parmakelis A, Russello MA, Caccone A, Marcondes CB, Costa J, Forattini OP, Sallum MAM, Wilkerson RC, Powell JR: Historical analysis of a near disaster: Anopheles gambiae in Brazil. Am J Trop Med Hyg 2008, 78:176-178.

38. Lounibos LP: Invasions by insect vectors of human disease. Annu Rev Entomol 2002, 47:233-266. 
39. Lambrechts L, Cohuet A, Robert V: Malaria vector. In Encyclopedia of invasive introduced species. Edited by: Simberloff D, Rejmànek M. Berkeley: University of California Press; 2011:442-445.

40. Reidenbach KR, Cook S, Bertone MA, Harbach RE, Wiegmann BM, Besansky NJ: Phylogenetic analysis and temporal diversification of mosquitoes (Diptera: Culicidae) based on nuclear genes and morphology. BMC Evol Biol 2009, 9:298.

41. Cogan BH, Hutson AM, Shaffer JC: Preliminary observations on the affinities and composition of the insect fauna of Aldabra. Phil Trans Roy Soc Lond. B 1971, 260:315-325.

42. Frith DW: A list of insects caught in light traps on West Island, Aldabra Atoll, Indian Ocean. Atoll Res Bull 1979, 225:1-13.

43. Brailovsky H, Barrera E: Two new species of Plinachtus Stål (Hemiptera: Heteroptera: Coreidae: Coreinae: Gonocerini) from Aldabra Atoll and Madagascar. Zootaxa 2006, 1351:35-43.

44. Goodman SM, Ranivo J: A new species of Triaenops (Mammalia, Chiroptera, Hipposideridae) from Aldabra Atoll, Picard Island (Seychelles). Zoosystema 2008, 30:681-693.

45. Convey P, Block W: Antarctic Diptera: Ecology, physiology and distribution. Eur J Entomol 1996, 93:1-13.

46. Gíslason GM: Af hverju lifa moskítóflugur ekki á Íslandi, fyrst pær geta lifað á Grænlandi? In Af hverju er himinninn blár? Edited by: Vilhjálmsson Th, Thorsteinsson JG. Reykjavík: Heimskringla Háskólaforlag Máls og menningar; 2003:61-62.

47. Laurence BR: Diptera in the northern isles of Britain. Entomol Month Mag 1997, 133:225-232.

48. Peterson BV: Diptera Nematocera. In The Zoology of The Faroes. Volume 2. Copenhagen: Andre. Fred. Høst \& sø; 1971:1-71.

49. Pennington M: Diptera true flies. [http://www.nature-shetland.co.uk/ entomology/diptera.htm].

50. Rageau J: Insectes et autres arthropodes d'intérêt médical ou vétérinaire en Nouvelle-Calédonie et aux lles Loyauté. Etud Mélanes 1955, 1011:60-104.

51. Laird M: A mosquito survey in New Caledonia and the Belep Islands. Bull Entomol Res 1954, 45:285-293.

52. Huang YM: The mosquitoes of Polynesia with a pictorial key to some species associated with filariasis and/or dengue fever. Mosa Syst 1977, 9:289-322.

53. Larish LB, Savage HM: Introduction and establishment of Aedes (Finlaya) japonicus japonicus (Theobald) on the island of Hawaii: implications for arbovirus transmission. J Am Mosq Contr Assoc 2005, 21:318-321.

54. van Riper C III, van Riper SG, Goff ML, Laird M: The epizootiology and ecological significance of malaria in Hawaiian landbirds. Ecological Monographs 1986, 56:327-344.

55. Atkinson CT, Woods KL, Dusek RJ, Sileo LS, Iko WM: Wildlife disease and conservation in Hawaii: pathogenicity of avian malaria (Plasmodium relictum) in experimentally infected liwi (Vestiaria coccinea). Parasitology 1995, 111(Suppl):S59-S69, 1995.

56. Nishida GM: Hawaiian terrestrial arthropod checklist. In Hawai'i Biological Survey 2002-005. Volume 22. 4 edition. Bishop Museum Technical Report; 2002:310.

57. Carvajal A, Adler GH: Biogeography of mammals on tropical Pacific islands. J Biogeogr 2005, 32:1561-1569.

58. Tempelis $\mathrm{CH}$ : Host feeding patterns of mosquitoes, with a review of advances in analysis of blood meals by serology. J Med Entomol 1975, 11:635-653.

59. Bruce-Chwatt LJ, Garrett-Jones C, Weitz B: Ten years' study (1955-64) of host selection by anopheline mosquitoes. Bull World Health Organ 1966, 35:405-439.

60. Adam JP: Transmission d'hemosporidies par des anophèles cavernicoles dans les grottes du Congo (Brazzaville). Bull World Health Organ 1965, 32:598-602.

61. Hervy JP, Le Goff G, Geoffroy B, Hervé JP, Manga L, Brunhes J: Les anophèles de la region afro-tropicale CD-ROM d'identification et d'enseignement. Paris: ORSTOM Ed; 1998

62. Daruty de Grandpré A, d'Emmery de Charmoy D: Les moustiques: anatomie, biologie, rôle dans la propagation de la malaria et de la filariose. Port-Louis: The planters and Commercial Gazette; 1900, 59.

63. Blanchard R: Moustique de La Réunion. Compte-Rendu Hebd Soc Biol 1902, 8:643-644 doi:10.1186/1475-2875-10-31

Cite this article as: Robert et al:: Why are anopheline mosquitoes not present in the Seychelles? Malaria Journal 2011 10:31.

\section{Submit your next manuscript to BioMed Central and take full advantage of:}

- Convenient online submission

- Thorough peer review

- No space constraints or color figure charges

- Immediate publication on acceptance

- Inclusion in PubMed, CAS, Scopus and Google Scholar

- Research which is freely available for redistribution 